Prekariat - perspektywa katolickiej nauki społecznej, red. J. Mazur OSPPE, ks. Ł. Marczak, Kraków 2017 (Spotkania Naukowe Wykładowców Katolickiej Nauki Społecznej, XIII), s. 121-136.

DOI: http://dx.doi.org/10.15633/9788374385985.07

Irena Lipowicz

Uniwersytet Kardynała Stefana Wyszyńskiego w Warszawie

\title{
Prekariat a prawa człowieka
}

Podstawowym źródłem praw człowieka i podstawą innych praw jest w świetle naszej konstytucji godność człowieka. Godność ta ma charakter bezwzględny ${ }^{1}$. Nie zależy ona od stanu zdrowia, stanowiska, pozycji społecznej - podlega powszechnej ochronie konstytucyjnej i ustawowej. Czy ustalenie w ostatnich latach wyodrębnionej grupy - o gorszej pozycji społecznej, większej niepewności zatrudnienia, niestabilnej pozycji życiowej² - a równocześnie takiej grupy, która nie jest jeszcze zbiorowością wykluczonych (bezrobotnych, bezdomnych ${ }^{3}$ ), narusza lub zagraża ich prawom w jednorodny sposób? Czy narusza prawa człowieka do ochrony zdrowia, edukacji, odpoczynku w taki sposób, że możemy wyodrębnić ją również ze względu na sytuację prawną?

Należy na wstępie określić kwestie pojęciowe. „Prekariat” jako określenie coraz wyraźniej wyodrębniającej się grupy ludzi

${ }^{1}$ M. Granat, Godność człowieka z art. 30 Konstytucji RP jako wartość i jako norma prawna, „Państwo i Prawo” (2014) nr 8, s. 3-22; R. Sobański, Normatywność godności człowieka, w: Godność człowieka a prawa ekonomiczne socjalne. Księga jubileuszowa wydana w piętnasta rocznicę ustanowienia Rzecznika Praw Obywatelskich, Warszawa 2003, s. 19-21.

2 G. Standing, Prekariat - nowa niebezpieczna klasa, Warszawa 2014; K. Cymbranowicz, Prekariat - nowe zjawisko na rynku pracy w Polsce, „Annales. Etyka w życiu gospodarczym /Annales. Ethics in Economic Life" 19 (2015) nr 2, s. 17-30.

3 Por. np. Bezdomność - problemy prawne, innowacyjne rozwiązania, red. I. Lipowicz, Warszawa 2016. 
pogrążających się w ubóstwie mimo wykonywanej stale - choć w różnych formach - pracy zawodowej, nieprzypadkowo został sformułowany jako pojęcie w USA. To tam po raz pierwszy odnotowano fenomen przyspieszonego rozwierania się nożyc dochodowych w sposób nieznany wcześniej w pokojowej historii kraju (poza okresami Wielkiego Kryzysu). Guy Standing określił tę grupę społeczną jako nową "klasę”, i to niebezpieczną ${ }^{4}$. Podejście klasowe, powrót do koncepcji „walki klasowej” w nowej odsłonie wskazuje na metodologię neomarksistowską, niezbyt szeroko obecnie akceptowaną w nauce zachodniej. A jednak samo pojęcie zrobiło światową karierę, trafiło bowiem w zapotrzebowanie na opis realnie występującej grupy społecznej. Inaczej niż chciał Standing nie jest ona analizowana jako niebezpieczna klasa, a raczej jako wyzwanie dla władz publicznych w prowadzonej przez nie polityce społecznej i fakt społeczny. Można oczywiście używać ostrożnie określenia „nowi ubodzy pracujący”, ale prekariat ma już „utarty” zakres znaczeniowy, choć czasem bywa ograniczany wyłącznie do osób młodych, startujących dopiero na rynku pracy - czego nie uważam za uzasadnione. Należy przypomnieć, że pojęcie „administracji świadczącej”, stworzone kiedyś przez Ernesta Forsthoffa ${ }^{5}$, jest modelem powszechnie używanym jako pojęcie-narzędzie, mimo że powstało w latach 30. w Niemczech i było w okresie faszyzmu wykorzystywane ideologicznie w szczególnie złym kontekście. Odzwierciedlało ono jednak także potrzebę ujęcia cywilizacyjnych zmian w roli administracji, stąd zostało adoptowane przez ustroje demokratyczne. Pojęcie prekariatu wywodzi się z teorii amerykańskiej, państwa prawa i demokratycznego ustroju, ale innego niż Europa, a autor określa prekariat jako klasę. Mimo całej odmienności uważam je za przydatne w polskiej nauce prawa administracyjnego, i to w szerszej wersji, nieograniczonej do osób młodych.

${ }^{4}$ G. Standing, Prekariat - nowa niebezpieczna klasa, dz. cyt.

${ }^{5}$ E. Forsthoff, Die Verwaltung als Leistungsträger, Stuttgart 1938. 
Trudno powiedzieć o generalnym naruszeniu godności człowieka przez samą przynależność do prekariatu. Można jednak ustalić naruszenie prawa do: wypoczynku (dyspozycyjność przez 24 godz. na dobę), mieszkania (kredyty tylko dla zatrudnionych na umowę o pracę), ochrony zdrowia (słabe ubezpieczenie zdrowotne przy umowach cywilnoprawnych), edukacji (brak szkolenia w pracy). Niepewność sytuacji życiowej i niskie dochody rzutują także na prawo do założenia rodziny i życia rodzinnego poprzez trudność uzyskania kredytu na mieszkanie, jego wynajem lub zakup, usamodzielnienie się. Ale i tutaj trudno byłoby na podstawie licznych stanów faktycznych - jak w przypadku innych praw socjalnych - wywieść bezpośrednią skargę konstytucyjną. Zbyt wiele zmiennych oddziałuje na ten stan, aby łatwo było skonstruować i przekształcić indywidualne roszczenie ${ }^{6}$.

Niezależnie od tego, czy będziemy się trzymać pojęcia prekariatu, czy też nie, mówiąc np. o „nowych ubogich-pracujących”, ochrona prawna osób zaliczanych do prekariatu jest trudna - np. masowa niestabilność zatrudnienia powoduje przewidywalne z góry kłopoty finansowe, częstsze bankructwa. Prawo powinno razem z polityką społeczną reagować na to, także dla zapewnienia stabilności całego państwa. Prawo pracy, prawo bankowe, prawo mieszkaniowe i prawo pomocy społecznej, które mogą wspierać obywateli w takiej sytuacji, wymagają modyfikacji. Taka zmiana prawa jest właściwa i celowa, jeżeli chcemy wpłynąć na liczebność tej grupy. Co można zrobić, aby poprawić sytuację całej nowej grupy społecznej? Co może zrobić parlament, administracja publiczna i Kościół?

Parlament powinien lepiej przestrzegać jakości prawa i jego treści jako sprawiedliwej regulacji ${ }^{7}$ - w rozumieniu sprawiedliwości

${ }^{6}$ Por. M. T. Romer, Godność człowieka w prawie pracy i pomocy społecznej, w: Godność człowieka a prawa ekonomiczne socjalne. Księga jubileuszowa... dz. cyt., s. 82-83, B. Godlewska-Bujak, Prekariat a umowy prekaryjne, „Praca i Zabezpieczenia Społeczne" (2014) nr 9, s. 3-5.

7 Piszę o tym szerzej w: Kilka uwag w kwestii racjonalności w prawie administracyjnym, w: Racjonalny ustawodawca. Racjonalna administracja. Pamięci 
społecznej - która nie może uprzywilejowywać bogatszych (np. poprzez indywidualne interpretacje podatkowe). Prawo bankowe, regulacja prawna prywatnej niewypłacalności, prawo egzekucyjne sprzyjają często bogatszym adresatom normy, na co wskazuje się w doktrynie prawa administracyjnego. To nic dziwnego, zważywszy na powracający stale w różnych ekipach politycznych outsourcing legislacyjny - zlecanie pisania projektów ustaw prywatnym kancelariom adwokackim, co znacznie ułatwia dostęp do nich szczególnie zamożnym grupom nacisku. Pilnej nowelizacji wymaga zwłaszcza ustawa o lobbingu i procedura sejmowa. Potrzebne jest jasne nazywanie poprawek do ustaw według nazwisk zgłaszających, uregulowanie statusu eksperta, obligatoryjne nagrywanie obrad podkomisji. Mijają lata i zmieniają się rządy, ale wciąż brak nowej ustawy o ekspertach - źródła wielu nieprawidłowości, np. w ekspertyzach karnistycznych, wskazywanych przez Rzecznika Praw Obywatelskich, a sytuacja prawna najsłabszych nie ulega zmianie ${ }^{8}$. Dotyczy to również np. ochrony zdrowia osób bezdomnych.

Należy powiedzieć otwarcie, że w przyszłości Polski i Europy nie będzie lepiej co do pewności zatrudnienia i wysokości zarobków większości zatrudnionych, ponieważ gwałtowne zmiany technologiczne sięgają już nie tylko robotyzacji pracy fizycznej, ale także automatyzacji pracy umysłowej - prawników i lekarzy, urzędników i nauczycieli, wspieranych, ale i wypieranych jako kategorie zawodowe informatycznie ${ }^{9}$. Według szacunków UE pracę straci ok. 40 proc. bezpośrednio zagrożonych digitalizacją. Sposobem, który pozwala sobie poradzić w zmieniającym się, niepewnym świecie, jest możliwie wszechstronne wykształcenie, kreatywność, odwaga w rozwiązywaniu przyszłych problemów.

Profesora Eugeniusza Smoktunowicza, red. D. R. Kijowski, A. Miruć, A. Budnik, Białystok 2016, s. 63-72.

8 Por. Sprawozdania z działalności Rzecznika Praw Obywatelskich w 2013, 2014, 2015, dostępne na www.rpo.gov.pl, a także I. Lipowicz, O mądre i wrażliwe prawo, Warszawa 2013.

9 R. Tomaszewska-Lipiec, Prekarna praca jako produkt wspótczesnej cywilizacji, „Przegląd Pedagogiczny” (2014) nr 2, s. 40-55. 
Należy przyjąć, że wielką rolę odgrywa obecnie lepsze wykształcenie, jednak już nie w tym sensie, aby broniło skutecznie przed utratą pracy, ale ponieważ pozwala szybko znaleźć nowe zatrudnienie, stworzyć firmę lub znaleźć ciekawą niszę rynkową. Dzięki dobremu wykształceniu lepiej rozumiemy zmieniający się świat i nowe możliwości - są to jasne rekomendacje dla zmiany polityki edukacyjnej i działań administracji publicznej w obszarze edukacji ustawicznej w tak niepewnym świecie.

Co może zrobić Kościół w sprawie prekariatu? Zastanówmy się, co wpędza młodych ludzi bez stałej umowy o pracę w poważne długi już na samym progu ich życia zawodowego? Rzadko są to koszty studiów jak w Ameryce, ale bywa, że są to koszty monstrualnego wesela (którego bardziej chciały rodziny niż młodzi) czy kredytu na mieszkanie (koniecznie własnościowego). To ostatnie pragnienie napędza też emigrację, mimo złudzeń typu ,jadę tylko zarobić na mieszkanie". Kościół mógłby przecież aktywnie nie tylko w pracy duszpasterskiej wypowiadać się w obu sprawach: „pomników klanowej pychy", którymi stały się niektóre wesela (stają się nimi nawet komunie święte). Limuzyna, dawniej atrybut ślubu, jest już wynajmowana na wieczór panieński, a licytacja kosztów trwa nadal. Należy pamiętać, że dodatkowo wzmacnia to patologiczny familizm ${ }^{10}$ polskiego społeczeństwa, na który od dawna wskazują socjologowie: system zależności i skomplikowanego rewanżu.

A w sprawie mieszkań? Władzom lokalnym, w okresie wyborów, zależy często na podkreślaniu swojej wierności wartościom, katolickiej nauce społecznej. Jasne poparcie Kościoła np. dla uzasadnionego zaspokajania potrzeb mieszkaniowych młodych ludzi przez budowanie mieszkań socjalnych i komunalnych zamiast luksusowych hal czy aquaparków i stadionów (niszowych) dyscyplin, jak to się dzieje nie tylko w Gorzowie Wielkopolskim czy Siemianowicach Śląskich, na pewno zostanie usłyszane. Nie można milczeć wobec braku aktywnej komunalnej polityki społecznej

10 Por. J. Czapiński, T. Paczek, Diagnoza społeczna 2013, Warszawa 2014. 
i jej archaiczności ${ }^{11}$. Tymczasem wystarczy zwykle deklarowana opcja światopoglądowa.

Kolejnym elementem spychającym szybko i nieodwracalnie rodzinę w grupę „ubogich pracujących" jest urodzenie się dziecka niepełnosprawnego, a zwłaszcza następujące zaraz potem (sięgające w niektórych rejonach kraju 90 proc.) porzucenie rodziny (głównie przez ojca dziecka). Podobnie jak niepłacenie alimentów przez ok. milion mężczyzn - nie staje się to stałym tematem homilii dla wiernych. Brak również stanowiska Kościoła (a to już na pewno ważna kwestia moralna) np. w sprawie niewykonania wyroku Trybunału Konstytucyjnego dotyczącego świadczeń dla opiekunów osób niepełnosprawnych, żyjących zwykle w ubóstwie. Rodzice dorosłego niepełnosprawnego dziecka to szczególnie doświadczona grupa prekariatu, do której nie można zaliczać wyłącznie młodych.

Czy taki postulat nie jest mrzonką? Czy Kościół katolicki w Polsce zachował wpływy w podobnych sprawach? Sądzę, że Kościół może uczynić wiele dobrego w tym zakresie. Niektórzy duchowni zwalniają już przecież niezamożnych młodych z opłat ślubnych. Wygrana została kiedyś batalia o jednolite stroje komunijne i komunie święte bez alkoholu. Świadomość postulowanej przez Kościół normy w tej kwestii trwa i jest ważna społecznie, mimo indywidualnych odstępstw. Sukces nie nastąpi od razu, nie będzie pełny, ale wiele rodzin przyjmie te napomnienia z ulgą, bo pozwoli im uwolnić się od swoistego „wyścigu zbrojeń”, na który często ich nie stać. Pierwsze ostentacyjnie „skromne” (np. z udziałem samego biskupa) wesela mogą stać się początkiem nowego trendu powściągliwości ${ }^{12} \mathrm{w}$ tym zakresie, podobnie jak aktywne zainteresowanie kwestią tanich mieszkań czy bezpłatnego transportu miejskiego.

${ }^{11} \mathrm{~K}$. Kłosowska-Lasek, Wpływ przemian cywilizacyjnych na działania społeczno-organizatorskie administracji, w: Wpływ przemian cywilizacyjnych, red. P. J. Suwaj, J. Zimmerman, Warszawa 2013, s. 210-213.

${ }^{12}$ M. Wlazło, Prekariat i niepetnosprawność - o tymczasowości i niepewności edukacji, rehabilitacji, pracy $i \dot{z} y c i a$, „Interdyscyplinarne Konteksty Pedagogiki Specjalnej" (2014) nr 6, s. 33-48. 
Należy się więc przygotować na nowe gwałtowne zmiany społeczne, które jednak mogą przynieść ze sobą także nowe możliwości. Grupa prekariatu (czy też „ubogich pracujących”) ma jedną ważną cechę, która odróżnia ją od poprzednich formacji najmniej zarabiających pracowników - mianowicie są wśród nich ludzie młodzi i świetnie wykształceni. To oni aktywnie kształtują nowe trendy i mody wśród swojego pokolenia. Jest zwyczajną koleją rzeczy racjonalizowanie swojej sytuacji nawet przez osoby bezdomne, a co dopiero przez osoby aktywne. Tak narodziła się niedawno „ekonomia dzielenia się" i świadome odrzucenie rozbuchanej konsumpcji. Była to trochę cnota wynikła z konieczności, ale stworzyła już kolejne nowe trendy. Należy do nich przekonanie, że wyznacznikiem statusu przestaje być posiadanie drogich „kultowych”, „markowych” przedmiotów wyprodukowanych przez wielkie światowe korporacje, a staje się posiadanie rzeczy trwałych i pięknych, czasem rękodzieła.

Popularne staje się zamienianie się rzeczami, a także dzielenie się np. własnym mieszkaniem w trakcie podróży i przyjmowanie gości za pośrednictwem sieci (tzw. couch surfing) albo podróżowanie z wykorzystaniem „okazji” samochodowej, a więc sytuacji, w której korzystamy z możliwości taniej podróży za cenę towarzyszenia właścicielowi pojazdu. Poruszanie się po mieście już nie własnym drogim samochodem, ale rowerem miejskim, a już wkrótce samochodem miejskim wypożyczanym za niewielką sumę, podobnie jak spotkania towarzyskie zwoływane za pomocą sieci społecznościowych, których celem jest zamienianie się ubiorami lub przeczytanymi książkami - te elementy wyznaczają nowy tryb życia, jego nowy styl i nie mają nic wspólnego z rozbuchaną konsumpcją. To także creative commons, open source i Wikipedia dzielenie się wiedzą - to wreszcie food truck - stylowe, wspólne "jedzenie z samochodu” zamiast w drogiej restauracji, stanowiące kiedyś szczyt mody, czy gotowanie dla kilku osób zwołanych przez Facebook zamiast korzystania z restauracji. Nowym pomysłem są także „mikrowyprawy” we własnym mieście, podejmowane w miejsce kosztownych dalekich podróży. 
Młode pokolenie dokonało już więc racjonalizacji swojej sytuacji i przeniosło ją w sferę wartości. To wielka szansa dla Kościoła, ponieważ wartości te są zbieżne z nauczaniem Kościoła katolickiego, który w ubóstwie i umiarkowaniu widział zawsze wartość w przeciwieństwie do kultu nieograniczonego bogacenia się ${ }^{13}$. Trzeba więc wspierać te trendy, chwalić i doceniać pomysłowość młodych ludzi, a nie ograniczać się do krytyki konsumpcjonizmu w sposób nudny i typowy przecież dla lat 90. (dla młodych to już całe wieki).

Niezwykle ważną kwestią jest problem statusu. Chodzi o to, że zamienianie się rzeczami, oszczędność zamiast kultury rzeczy jednorazowego użytku powoduje korzystne zmiany społeczne, zmniejsza przepaść między bogatymi a biednymi. Bo rzeczy, którymi mogą szczycić się bogaci, przestają być wyznacznikiem statusu dla młodych. To skomplikowany proces i nie może oczywiście zamaskować na dłuższą metę zwyczajnej biedy, jest jednak odważną i nowatorską drogą, i w moim przekonaniu spowoduje trwałe przesunięcie w sferze wartości, a dopiero następnie zmianę instytucji życia publicznego ${ }^{14}$. Można ten trend wspierać w skali Europy i kraju. W domach parafialnych można przecież organizować zamienianie się rzeczami dla dzieci, książkami, zabawkami.

Dalekosiężnym celem może być w nauczaniu Kościoła także ogólne przyspieszenie zawierania małżeństw i prokreacji na okres studiów. Jest to naprawdę polska szansa. Oczywiście będą to głównie rodziny prekaryjne i dlatego trzeba wrócić do „rodzinnych" akademików, żłobków i przedszkoli uniwersyteckich, które mogłyby być wspierane przez Kościół, a przede wszystkim do akceptacji tego procesu. Obecnie w miastach małżeństwa zawierane są zbyt późno, aby to mogło odwrócić niekorzystny trend demograficzny. A rozwój wielkich miast jest faktem.

13 Oczywiście najbardziej nośna jest „moda” na transport publiczny, patrz np. artykuły na www.transport-publiczny.pl.

${ }^{14}$ M. Małecka-Łyszczek, Wpływ wybranych prawnych form działania administracji na natężenie wspólpracy z podmiotami ekonomii społecznej, „Ekonomia Społeczna" (2013) nr 3, s. 103n. 
Administracja to ekonomia społeczna, która daje szansę wyjścia z prekariatu, a nie tylko z bezdomności. Administracja centralna powinna wspierać i przygotowywać odpowiednie ustawodawstwo. Samorząd terytorialny może ją wspierać przez klauzule socjalne (społeczne) w statutach miast i gmin, pozwalające dawać przy przetargach gminnych pierwszeństwo spółdzielniom socjalnym np. bezrobotnych absolwentów lub innych ubogich pracujących (np. emerytów). Ekonomia społeczna jest w pełni zgodna z katolicka nauką społeczną, lecz zbyt mało znana i propagowana.

Szkoła i Kościół powinny informować wyczerpująco o konsekwencjach emigracji - nie tylko o sukcesach, ale także o typowo słowiańskiej nostalgii, upokorzeniu, samotności emigranta. Nie można przemilczać przypadków nienawiści do nich (jako cudzoziemców), z którą się spotykają. Prawdziwy prekariat dzisiaj to właśnie emigrujący czasowo Polacy i Polki, podejmujący pracę robotników budowlanych, opiekunek, a nie wyjątki pracujące w korporacjach. Kościół w Polsce jest dla nich ostoją, a raczej ucieczką, niż bazą do wyjścia $\mathrm{w}$ świat, ale brak jest porozumień z miejscowymi diecezjami. Wyjątkiem jest praca Caritasu w Niemczech: wypracowany tam został model porozumienia $\mathrm{z}$ diecezją Paderborn, ale brak jego upowszechniania.

Co możemy zrobić wspólnie?

1. „Oderwać” symbolicznie poczucie godności człowieka od bycia pracownikiem, podkreślić np. godność bezrobotnego, emigranta. Godność człowieka, godność obywatelska są samoistne i nie wynikają z umowy o pracę. Istnieje odrębna godność pracy, ale nie wolno definiować człowieka tylko przez pracę. Brak wyeksponowania tej prawdy w nauczaniu społecznym.

2. Kształcić jeszcze bardziej wszechstronnie - pomagać w kryzysach - dawać ochronę wspólnoty ${ }^{15}$. Taka triada będzie bardziej odporna na kryzysy, choć im nie zapobiegnie.

${ }^{15}$ M. Przybylski, Prekariat w lokalnej polityce społecznej województwa łódzkiego, w: Samorządowa polityka społeczna. Wyzwania i działania, red. J. Przywojska, Łódź 2015. 
3. Wspierać i rozwijać trend sharing economy - ekonomii dzielenia się dać silną akceptacją społeczną, a także akceptację Kościoła;

4. Dowartościować cnotę odwagi, męstwa, gotowości na zmiany, dawać nadzieję, zamiast przytakiwać „wyuczonej bezradności” i eskalować poczucie klęski życiowej oraz całkowitej zależności od państwa. Zbyt często takie tony pojawiają się w nauczaniu publicznym i w Kościele, bo to dużo łatwiejsze niż wymaganie pomocy od siebie wzajemnie i od wspólnoty parafialnej.

Pilnej modyfikacji wymaga prawo pracy, i to zarówno w działaniach parlamentu, jak i administracji. Jeżeli - jak wskazuje się w literaturze - zaledwie ok. 10 proc. ofert pracy przechodzi realnie przez urzędy pracy, reszta pozostaje $\mathrm{w}$ internecie oraz $\mathrm{w}$ sferze kontaktów nieformalnych, a tylko ok. 5-6 proc. bezrobotnych otrzymuje realne oferty szkoleń i staży, to nie można przypisywać odpowiedzialności tylko pracownikom urzędów samorządu powiatowego. Trzeba uwolnić ich inwencję oraz innowacyjność i za nią wynagradzać, a nie bez końca uszczegóławiać ich obowiązki sprawozdawcze i przepisy krępujące działania niestandardowe. Administracja pracy musi głębiej wejść w erę digitalizacji, a prawo powinno na to pozwalać, egzekwując w czasach "pracy niepewnej” poszanowanie godności pracowniczej - jako ważnego rodzaju godności człowieka. Wymaga to oszczędnej, powściągliwej regulacji, która pozostawia przestrzeń do elastycznego działania administracji.

Czy jest tu także miejsce na działanie Kościoła katolickiego lub innych Kościołów? „Praca na etat” jako najwyższe dobro szanowane przez starsze pokolenie jest często kwestionowana przez młodych, przyzwyczajonych już od początku do „pracy niepewnej” i akceptujących jej blaski i cienie. To często przedmiot konfliktów rodzinnych. Starsi nie zawsze mają rację, jeśli okres prekariatu jest tylko wstępem do stworzenia firm typu start-up i kariery przedsiębiorcy. Czasami właśnie w tym zakresie ważne byłoby wsparcie duszpasterskie dla poszanowania wolności decyzji, usprawiedli- 
wionego ryzyka i odwagi młodego pokolenia. Polska staje się krajem ludzi starszych w naturalny sposób stroniących od ryzyka, co może zagrozić naszej przyszłości gospodarczej i uczynić pracę jeszcze bardziej niepewną.

Mimo trwającej dyskusji wokół samego pojęcia prekariatu, utrwaliło się ono od $2011 \mathrm{r}$. w wersji Standinga ${ }^{16}$ i ułatwia debatę międzynarodową. Grupa ta (choć nie klasa w rozumieniu Standinga) nie jest także jednorodna wiekowo. Wraz z pogarszającą się sytuacją gospodarczą i obniżeniem się emerytur szeregi tej grupy będą stale zasilały osoby starsze, dorabiające do emerytury lub wręcz zarabiające na życie wobec jej całkowitego braku. Dotychczas nie ma wypracowanych metod pomocy dla tej kategorii osób pracujących, która uwzględniałaby zasady deinstytucjonalizacji. Odmiennie niż osoby starsze z bogatszych krajów zachodnich, Polacy nie mają zwykle w rodzinie długoletnich oszczędności, a do wpadnięcia w ubóstwo wystarczy konieczność remontu lub choroba $\mathrm{w}$ rodzinie. Brak młodych pracowników spowoduje jednak w przyszłości pojawianie się nowej niskopłatnej pracy także dla osób powyżej 65. roku życia, pozbawionych środków do życia. Oznaczać to będzie zasilenie prekariatu przez grupę osób nawet w wieku emerytalnym. Również ta zmiana wymaga odpowiedniej reakcji w zakresie stosowania nowych prawnych form działania administracji ${ }^{17}$ i szerokiego oparcia społecznego ${ }^{18}$, w tym modyfikacji polityki wobec zatrudnienia w trybie umów cywilnoprawnych. Konieczne jest także rozszerzenie - wobec zatrudniania i młodszych, i starszych prekariuszy - kontroli Państwowej Inspekcji Pracy na wszystkie formy świadczenia pracy.

16 Por. G. Standing, Prekariat - nowa niebezpieczna klasa, dz. cyt.; R. Tomaszewska-Lipiec, Prekarna praca jako produkt współczesny, dz. cyt.

17 Piszę o tym szerzej w artykule na temat prawnych form działania administracji: Prawne formy działania administracji - między stabilizacją a potrzeba przełomu, „Ruch Prawniczy, Ekonomiczny i Socjologiczny” 2016, nr 4, s. 41 i n.

18 B. Golewska-Bujak, Prekariat a umowy prekaryjne. Głos $w$ dyskusji, „Praca i Zabezpieczenie Społeczne" (2014) nr 9, s. 2-6. 
Jako trwałe wyjście z zagrożenia jawi się jednak przyjęcie zasady zrównoważonej konsumpcji - jednego z elementów zasady zrównoważonego rozwoju. Dla samorządu terytorialnego oznacza ona, że potrzeby podstawowe wspólnoty są realizowane jako pierwsze, a ostentacyjna konsumpcja, również zbiorowa, będąca elementem konkurencji, musi ustąpić zrównoważonemu, racjonalnemu zaspokajaniu potrzeb mieszkańców (a więc wydatki na mieszkania komunalne i żłobki będą przed dotacjami dla prywatnych klubów sportowych i nowym ratuszem). Dla młodych rodzin kluczowy jest „syndrom drugiego roku” - luka między rocznym urlopem macierzyńskim a nabyciem prawa do przedszkola. Młoda rodzina, obciążona już kredytem, płaci dużo za opiekunkę lub prywatny żłobek, bo miejsc w publicznych żłobkach wciąż brak. Jeżeli jednak po roku matka nie wróci na rynek pracy, ryzykuje długotrwałe bezrobocie - katastrofę dla budżetu rodzinnego. Wpłynie to na jej decyzję o dzietności. Kościół przez lata prowadził ochronki - dziś wystarczy, że będzie się upominał o prawa młodych rodzin i nie krytykował instytucji żłobków jako takich, skoro wiele rodzin nie ma innego wyjścia w zakresie opieki na dzieckiem.

Zrównoważona konsumpcja stanowi ważną część zasady zrównoważonego rozwoju i powinna stać się zasadą prawną, realnie wpływającą na zadania samorządu i administracji centralnej. $\mathrm{Na}$ czym polega (przykładowo) aktywna polityka lokalna dotycząca zrównoważonej, integralnej konsumpcji jako części zrównoważonego rozwoju? To, po pierwsze, zadanie sobie przez radę miasta (gminy) pytań: czy podstawowe potrzeby mieszkańców gminy zostały już zaspokojone czy właściwie dbamy o słabszych, czy wyprowadzamy z bezdomności, czy pomagamy profesjonalnie ubogim, rodzinom wielodzietnym, seniorom i osobom niepełnosprawnym? Jaka część budżetu jest na to przeznaczona (jak wygląda alokacja środków publicznych?) Czy pokazowe inwestycje komunalne, do których skłaniają przedsiębiorcy (na przykład aquaparki), będą ekonomiczne w utrzymaniu, czy też na lata zrujnują budżet gminy? W pełni uzasadnione jest angażowanie gmi- 
ny w pobudzanie rozwoju gospodarczego, ale spójność społeczna, zapobieganie depopulacji, mieszkania komunalne i żłobki (wielki wydatek dla młodych rodzin) są ważniejsze i zapewniają lepszą równowagę społeczną. Mogą też powstrzymać ucieczkę młodych z danej miejscowości. Stopniowo wzrost PKB jako miernik sukcesu w rządzeniu państwem jest zastępowany przez wskaźnik zrównoważonego rozwoju. W Polsce wskaźnik ten dramatycznie w ostatnich latach spada, odrywa się od wzrostu PKB. Regres ten nie został zatrzymany w ostatnich miesiącach zmianą rządu nadal postępuje. O ten wskaźnik na poziomie centralnym powinien stale pytać Kościół, np. w ramach Komisji Wspólnej, bo jego obecny spadek zwiastuje przyszłe poważne wstrząsy społeczne, na które Kościół musi się dopiero przygotować. Tak ważne społecznie programy, jak Rodzina 500 Plus, działają tylko jak chwilowe znieczulenie stanu zapalnego.

Innowacyjność społeczna jawi się jako dobry sposób na wyjście z zagrożenia - może być chroniona i wspierana także przez Kościół. Dobre praktyki w odniesieniu do prekariatu to często właśnie innowacje społeczne, które powinny być doceniane społecznie i wprowadzane w główny nurt polityki publicznej. Opóźnione zastosowanie takich innowacji - najlepiej sprawdzonych w projekcie pilotażowym na ograniczonym obszarze - kosztuje w warunkach globalizacji bardzo wiele. Trwanie przy archaicznych, nieskutecznych formach ochrony przed wykluczeniem społecznym uszczupla pulę ograniczonych środków publicznych ${ }^{19}$. Sukces w tej metodzie modernizacji odniosły (z ważnym i bolesnym wyjątkiem ,ideologicznie" odrzuconych praw człowieka) ostatnio Chiny. Nawet one poszukują na całym świecie skutecznych metod rozwiązywania nowych problemów społecznych (takich jak u nas rosnący szybko prekariat), następnie testują je $\mathrm{w}$ jednym $\mathrm{z}$ regionów, aby potem

19 A. Kolek, „Prekariat” jako nowa klasa społeczna. Geneza, istota, wyzwania, https://depot.ceon.pl/bitstream/handle/123456789/3301/Prekariat_jako\%20nowa\%20klasa\%20spo\%C5\%82eczna.\%20Geneza,\%20istota,\%20wyzwania_.pdf? sequence=1) (30.12.2016). 
szybko wprowadzić w ogromnej skali. Polska ma tymczasem możliwość wprowadzania wielu innowacji społecznych wypróbowanych już w całej Europie i tym bardziej powinna z nich skorzystać, zamiast zamykać się na Europę. Włoska ekonomia społeczna, duńskie wyprowadzanie $\mathrm{z}$ bezdomności, niemieckie wspieranie młodych wchodzących na rynek pracy to świetne przykłady.

Zmodyfikować należy częściowo system prawa; prawo do pracy, mieszkania, wypoczynku, stabilności życiowej powinno być objęte monitoringiem - każdy projekt powinien być oceniany pod tym kątem, czy nie przyczynia się do zwiększenia skali ubóstwa społecznego, i dopiero wtedy procedowany. Pilnego rozwiązania wymaga kwestia ustawy reprywatyzacyjnej. Nagła utrata mieszkania przy obecnej chaotycznej reprywatyzacji nieuchronnie wtrąca w ubóstwo nawet osoby pracujące, nie tylko emerytów. Głos Kościoła w rozwiązaniu odkładanej od lat kwestii reprywatyzacji w duchu sprawiedliwości społecznej miałby wielką wagę, a katolicka nauka społeczna podpowiada logiczne rozwiązania.

Ważną częścią prekariatu są pielęgniarki jako grupa zawodowa. Rażąco niskie ich wynagrodzenia spowodowały, że średnia wieku tej grupy zawodowej w Polsce to 49 lat. Bez wsparcia z zagranicy w świadczeniu opieki zdrowotnej (Ukraina) system ten dawno uległby załamaniu. Generalnie niskie płace kobiet w zawodach opiekuńczych to ważne źródło powstania prekariatu, ale także masowej emigracji. Autorytety społeczne i kościelne milczą także w tej sprawie.

Depopulacja (trwały ubytek ludności) całych powiatów i województw staje się faktem i wymaga aktywnej polityki społecznej, ale także większej integracji i partycypacji społecznej. Trudno jeszcze odnaleźć na razie oficjalne stanowisko Kościoła w sprawie postępującej depopulacji, choć istnieją już takie dokumenty administracji samorządowej (Opole). Poza Stowarzyszeniem „Barka” w Poznaniu brak także wspieranych przez Kościół samorządowych programów „powrotowych” dla tych, którzy ponieśli klęskę ekonomiczną na emigracji, a boją się wrócić, aby nie być 
ciężarem dla rodziny. Miałoby to wielkie znaczenie społeczne. Program taki jest szczególnie pilny także w perspektywie Brexitu.

\section{Podsumowanie}

Reasumując, prekariat to jedna z „rzeczy nowych”, którym muszą stawiać czoło państwo, ale także Kościół i sami pracujący. Ważne, aby poszukiwanie metod i form działania odbywało się z poszanowaniem podstawowych wartości konstytucyjnych - głównie godności człowieka. Prekariat to zbiorcze określenie kategorii osób, które mimo wykonywanej starannie pracy osuwają się stopniowo poniżej granicy ubóstwa, bez własnej winy mają trudności z zaspokajaniem podstawowych potrzeb własnych i swojej rodziny. Najprostszą metodą wydaje się znaczące podniesienie płacy minimalnej i wysokie zasiłki socjalne, w tym rodzinne. Jeżeli jednak nie jest to możliwe ze względu na sytuację ekonomiczną (a prekariat rośnie nawet w najbogatszych krajach), należy poszukiwać dodatkowych rozwiązań w warunkach ramowych, jakie społeczeństwo, Kościoły i państwo oferują tej grupie społecznej. Wskaźnik Giniego ${ }^{20}$ nie jest jeszcze w Polsce wysoki, a nawet okresowo maleje, ale nie mamy pewności, czy jest on stale monitorowany w naukowych kręgach kościelnych. Tymczasem, jak wskazuje przykład Brazylii, Meksyku czy Hiszpanii, jest on zawsze znakomitym sygnałem alarmowym ukazującym stan spójności społecznej i powinien również wywoływać adekwatną reakcję autorytetów społecznych. Na marginesie należy zauważyć, że obojętność na ich destrukcję w toku ostrej walki politycznej oznacza demontaż ważnych „bezpieczników” na czas zagrożenia, wojny czy ciężkiego kryzysu ekonomicznego. Czy prekariat jest wyjątkiem? W ciągu 25 lat pojawiły się w Polsce oprócz prekariatu co najmniej

${ }^{20}$ Wskazujący na rozpiętość dochodów między bogatymi a biednymi. P. Maciejewicz, Mniejsze nierówności w Polsce, „Gazeta Wyborcza” z 15 września 2016 r., s. 8. 
dwie nowe grupy społeczne: wąska grupa ludzi naprawdę bogatych oraz duża grupa ludzi powyżej 80., a nawet powyżej 85. roku życia. Charakterystyczna jest również tutaj pewna bezradność w podejściu do nowych grup ze strony państwa (partnerstwo społeczne, podatki), Kościoła i partii politycznych - nie dotyczy to więc tylko prekariatu. Brak przykładowo uznanych społecznie w ustabilizowanych krajach zachodnich mechanizmów dzielenia się bogactwem na rzecz edukacji, potrzeb osób niepełnosprawnych czy dzieci. Brak także zaakceptowanej przez Kościół katolicki generalnej polityki „senioralnej” dla osób w wieku 80+, wykraczającej poza tradycyjne metody duszpasterstwa i opieki, a uwzględniającej liczne pożyteczne innowacje umożliwiające osobom starszym długie pozostanie w miejscu zamieszkania, pielęgnowanie w domu, udział wolontariuszy w załatwianiu spraw życia codziennego i remontu. Przez aktywność Caritas prawdopodobnie i inne podmioty często czują się zwolnione z zaangażowania.

Kościół potrafił w przeszłości - już za czasów Leona XIII mądrze i profetycznie reagować na gwałtowne zmiany społeczne. Tak narodziły się kiedyś zarówno zasada pomocniczości, jak i idea integracji europejskiej. Obecne działania papieża Franciszka dotyczą jeszcze głównie odpowiedzialności indywidualnej i zadań państwa w planie ogólnym w związku z gwałtownością procesów migracyjnych, ale możemy spodziewać się wkrótce powstania nowej, całościowej doktryny reagującej na spiętrzenie nie do końca jeszcze nazwanego wielkiego przełomu społecznego, będącego również konsekwencją rewolucji informacyjnej (tak jak wcześniej Rerum novarum było odpowiedzią na rewolucję przemysłową). Ważne jest, aby polska nauka potrafiła aktywnie uczestniczyć w tym poszukiwaniu, przedstawiając własne propozycje w ramach katolickiej nauki społecznej. 